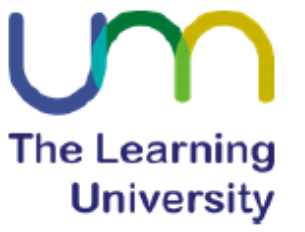

Icssh, 1(1), 2017

PROCEEDINGS

The Ist International Conference on Sports Science and

Health

\title{
IMPLEMENTATION OF RECREATIONAL AND TRADITIONAL SPORT FESTIVAL FOR IMPROVING COMMUNITY ECONOMY
}

\author{
Ghon Lisdiantoro, Universitas PGRI Madiun \\ Pratama Dharmika Nugraha, Universitas PGRI Madiun \\ Enggel bayu pratama, Universitas PGRI Madiun \\ Email: ghontaro@gmail.com
}

\begin{abstract}
Improving the economy of the community is one of the Government programs. Increasing the economy through the sports industry could be a booster for the economy of the people. One form of the sports industry can take the form of sales services of sports activities as a professionally packed product such as the organization of sports festivals. Sports festivals professionally packed by organizing recreational and traditional sporting events will certainly involve many parties including organizers, government, recreational sports communities, traditional sports communities, merchants, sponsors, etc. The interaction that occurs in the organization of recreational and traditional sports festivals between the various parties will automatically disrupt the economic passion in the area where the implementation of these activities. The implementation of recreational and traditional sports festivals can certainly help one of the Government programs to improve the economy of the community. In addition to improving the economy, these activities help to preserve and popularize traditional and recreational sports and provide a sporting activity that can be followed by various levels and ages.
\end{abstract}

Keywords: Sports Festival, Sports Recreation, Traditional Sport.

Sports are all systematic activities to encourage, nurture, and develop physical, spiritual, and social potential. Sports activity is an activity that is often done people from various walks and levels of age, although the sport is different. "To socialize sports and to cultivate the community" is one of Soekarno ( 1 st President of Indonesia) programs when trying to build this nation. The sentence has a very profound meaning for the progress of the nation. Because a nation that has high health and good fitness will be a great nation. Health and fitness is a person's capital to work and work to maintain his life by running the wheels of the economy.

Exercise can be done as an exercise, education, entertainment, recreation, achievement, profession, politics, business, industry, and various other aspects of human culture. Among the community has created various kinds of traditional sports are embodied in a form of traditional games as a means of entertainment. Although as a means of entertainment, these activities can also have an impact on health because there are elements of physical activity and generate a sense of pleasure that positively impact the psychological condition. A number of studies suggest that there is a positive relationship between involvement in sports with a person's psychic condition (Biddle, Sallis, \& Cavill, 1988). Those who are actively engaged in sports activities show a higher level of confidence (self confidence) than those not involved (Maksum, 2008: 170).

In addition, in this era of globalization people are busy with work that becomes routine in everyday life so that people need time for recovery again. Sports recreation can be a solution to eliminate fatigue after people are busy running various activities. Sports recreation is a sport that can be done by various circles. The government provided the vessel through the Federation of Sports Recreation Communities (FORMI) to oversee recreational and traditional sports activities. 


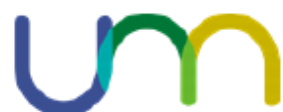

The Learning

University
Icssh, 1(1), 2017

PROCEEDINGS

The Ist International Conference on Sports Science and Health

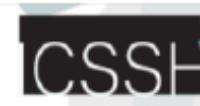

International Conlarence
on Sport Scences ond heoth

Sports festival is one solution to help improve the economy of the community. Sports festivals professionally packed by organizing recreational and traditional sporting events will certainly involve many parties including organizers, government, recreational sports communities, traditional sports communities, merchants, sponsors, etc. The interaction that occurs in the organization of recreational and traditional sports festivals between the various parties will automatically disrupt the economic passion in the area where the implementation of these activities. The implementation of recreational and traditional sports festivals can certainly help one of the Government programs to improve the economy of the community. In addition to improving the economy, these activities help to preserve and popularize traditional and recreational sports and provide a sporting activity that can be followed by various levels and ages.

\section{DISCUSSION}

\section{Sport Recreations}

In UUSKN NO. 3 Year 2005 CHAPTER I Article 1 mentioned, sports recreation is a sport conducted by the community with passion and ability that grow and develop in accordance with the conditions and cultural values of local communities for health, fitness, and fun. Sports recreation activities undertaken are part of the health and fitness restoration process. Sports recreation is an activity that can be performed by any person, educational unit, institution, association, or sports organization.

In line with the demands of the times and development of sports as part of the recreational sport listed in Law No. 3 of 2005 on the National Sport System CHAPTER VI Article 17 which states that the scope of sports includes sports activities education, sports recreation and sports achievements. Based on the description of article 17 where there is a recreational phrase it makes consideration to change the name of FOMI to FORMI (Federation of Sports Recreation Society of Indonesia).

Table 1. Branches of Sports Recreation of Communities Merged within FORMI

\begin{tabular}{|l|l|l|}
\hline $\begin{array}{l}\text { Sports Fitness } \\
\text { Gymnastics Branch }\end{array}$ & Sports Creativity & Traditional Sports \\
\hline 1. Brain Gymnastics & & 1. Gobak Sodor / Hadang \\
2. Perwatusi Gymnastics & 1. Poco-Poco & 2. Drive \\
3. Gymnastics Diabet & 2. Rechadut & 3. Long teklek \\
4. Healthy Gymnastics & 3. Recha & 4. Pedaki Mountain \\
5. Gymnastics Exercise & 4. Pocharina & 5. Rafting \\
(PORPI) & 5. Line Dance & 6. BMX \\
6. Healthy Gymnastics & 6. Sajojo & 7. Panco \\
Indonesia (Ssi) & 7. Cheer Leader & 8. Gas \\
7. Aerobic Gymnastics & 8. Modern Dance & 9. Paragliding \\
8. Gymnastics Tera & & 10. Lions \\
Indonesia Gymnastics & & 11. Patak Catfish \\
Asthma Indonesia & & 12. Betengan \\
9. Elderly Gymnastics & & 13. Tonnis \\
10. Gymnastics Satria & & 14. Casual Bicycle \\
Nusantara. & & 15. Healthy Walk \\
\hline
\end{tabular}




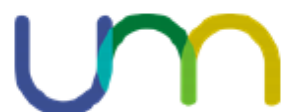

The Learning University
Icssh, 1(1), 2017

PROCEEDINGS

The Ist International Conference on Sports Science and Health

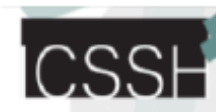

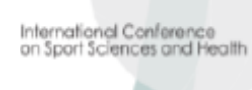

commonly called traditional art can also be included. An activity categorized as traditional sports must be identified elements of tradition that have a close relationship with the customs or customs of a particular group of people (Suprayitno, 2014: 9). These activities must be strongly contained physical elements that clearly involve large muscle groups. In subsequent developments, traditional sports are often used as a type of game that uses the original regional characteristics and adapted to local cultural traditions.

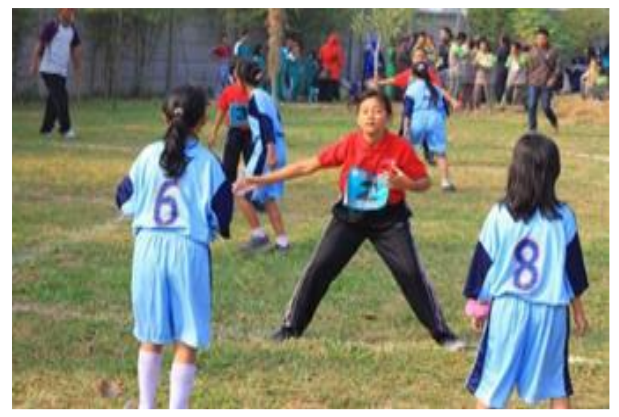

\section{Figure 1. Gobak Sodor}

The activities of traditional sports are performed both regularly and occasionally with the intention to seek entertainment and fill the spare time after regardless of activities that become routines. For example, students who have learning rutinas in school can mngisi spare time by performing traditional games. Sports that are traditional traders at FORPI include: gobak sodor / hadang, dagongan, teklek long, pedaki mountain, white water rafting, BMX, panco, gas, paragliding, lion dance, catfish, tin, tonnis, bike relax, healthy road.

\section{Economic Sectors And Sports}

According to data from the ministry of PPN/Bappenas in the 2017 Indonesia Economic Outlook report, the 2017 APBN set the assumption of Indonesia's economic growth target in 2017 of 5.1 percent. Nevertheless, the achievement of such economic growth targets will largely depend on several factors. First, the effectiveness of Government policy in mitigating future economic risks, both domestic and foreign. Second, the success of economic reform that has been running for the last 2 (two) years. One of the domestic challenges to achieve economic growth targets is the lack of optimal state revenues from taxes, in line with Indonesia's economic slowdown and low tax base. On the other hand, the Government plans to increase the share of its expenditure budget, particularly for infrastructure spending, to reduce the infrastructure gap between regions and as a driver of Indonesia's economic growth. As a result, the budget deficit tends to widen and approach the threshold stipulated in the regulation stating that the cumulative amount of budget deficit can not exceed 3 (three) percent of GDP in the current year. Another domestic challenge is private sector activity which is still relatively stagnant until the second quarter of 2016, one of which is reflected in the slow growth of credit. In addition, the increase in NPLs in the banking sector is one of the risks that need to be closely monitored by the Government. With the Government's increasingly limited space for the decline in tax revenues, the Government can not freely increase its spending, the 


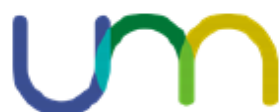

The Learning University
Icssh, 1(1), 2017

PROCEEDINGS

The Ist International Conference on Sports Science and Health

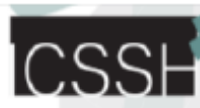

International Conterence
on Sport Scences and heath

role of the private sector as a source of economic growth needs to be continuously encouraged and enhanced.

The private sector and the Government can be able to collaborate with each other in order to promote national economic growth. The sports sector can be a sector that allows for such collaboration. Not only the economic sector, but can also be a cooperation to improve the dignity of the nation through the sports sector. We certainly have often encountered the involvement of the private sector in a sporting event, both multi-sport and a particular sports capbang. Cooperation that is solidly established between the Government and the private sector in the sports sector can certainly have a positive impact on people's lives. If a private sector engaged in services or in the form of a particular product to sponsor the community will be more familiar with the products of the company concerned. Once the product is known to the public then the possibility to sell will be greater, and if sold prosperity workers in the company will increase. The private sector and the Government can work together to finance so that a sports competition can take place, so as to improve the welfare of athletes, coaches, sportswear manufacturers, food traders and people who depend on sports.

\section{Impact Of Recreational And Trusional Sport Festivals To The Economy}

The development of sports is an integral part of the national development process, especially in the effort to improve the quality of human resources that leads to: (1) the improvement of people's physical health, (2) the spiritual mental qualities of the community, (3) the formation of the nation's character and personality; ) discipline and sportsmanship, and (5) improvement in achievement that can evoke a sense of national kebengga (Agus Kritiyanto, 2012: 1). These five points are big capital to build the national economy. Because to build a strong economy needs to be based on building a strong foundation in the form of healthy human resources, noble and honest character, and have a high discipline in working

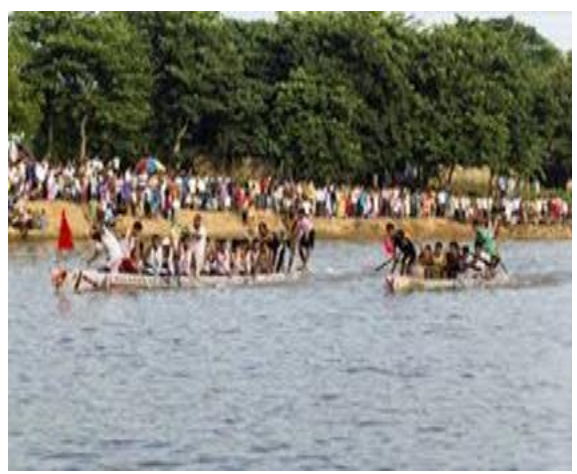

Figure 2. Rowing

Organizing a sports event is an activity that is usually done in the community. These activities usually contain various games and competitions. So it can be concluded that the organization of sports events is not a new thing in the cultural development of our society. Organizing a professionally packed sporting event can be a sports industry that can improve the economy of the community. The discussion of the sports industry means discussing endless opportunities and challenges, but these opportunities and challenges are a very challenging potential as a "giant" (Kristiyanto, 2012: 229). 


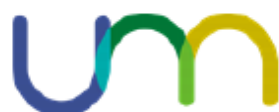

The Learning

University
Icssh, 1(1), 2017

PROCEEDINGS

The Ist International Conference on Sports Science and Health

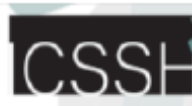

Internationd Conterence
on Sport Scences and heoth

Organizing sports events that can involve the public much of course will increasingly have a positive impact for economic growth for the community around the event. Recreational and traditional sports festivals can be a form of sports that can involve various components of society. The community involved as a participant may consist of various ages and ages. For the organizing committee can involve the Government, the sponsors, as well as various recreational and traditional sports communities. As a complement of course there will be many traders who sell a variety of foods and beverages at the location of the festival sports and traditional leisure. For the implementation of these activities would require equipment. The necessary equipment may be purchased at the store and can be ordered from the craftsman or manufacturer of the specific equipment required for the race and match.

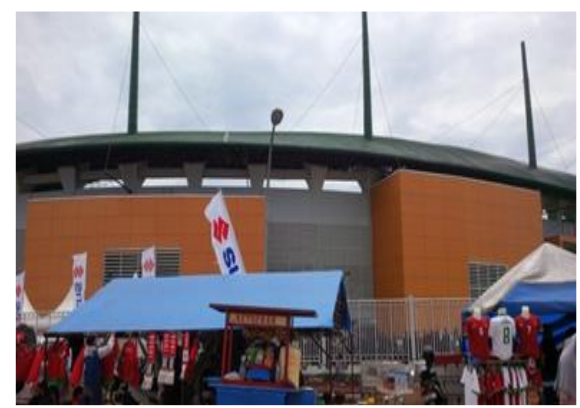

Figure 3. Economic interaction at the site sports events

Interactions that occur from among the components of the community, whether they act as organizers, participants, equipment providers and matches, and traders at the activity locale will bring economic activity. Economic activity is certainly able to help government programs to improve the economy of the community. A professionally organized sports festival can provide widespread financial income for the community at large, especially in locations where the activity is being held. Recreational and traditional sports festivals are part of the sports industry, this is what is meant by the great potential of the sports industry.

\section{CONCLUSION}

Based on the results of the above exposure, it can be concluded that with the emergence of a sports festival event will bring a positive impact on the economic level of local residents. Organizing a well-planned and well-planned sports event can absorb the power and contribution of the community, will certainly have a positive impact for economic growth for the community around the event. Thus, recreational sports and traditional sports generally have a positive impact on increasing economic levels for poverty alleviation and unemployment of local people.

\section{REFERENCES}

Kristiyanto, Agus. 2012. Pembangunan Olahraga Untuk Kesejahteraan Rakyat Dan Kejaan Bangsa. Surakarta: Yuma pustaka. 
Kementerian PPN/Bappenas. Outlook Perekonomian Indonesia 2017 (tantangan menghadapi resiko global). Jakarta: Kementerian Perencanaan Pembangunan Nasional/Badan Perencanaan Pembangunan Nasional Republik Indonesia.

Maksum, Ali. 2008. Psikologi olahraga teori dan aplikasi. Surabaya: UNESA Press.

Undang-Undang Republik Indonesia Nomor 3 Tahun 2005 Tentang Sistem Keolahragaan Nasional, Jakarta: Biro Humas Dan Hukum Kementerian Negara Pemuda Dan Olahraga Republik Indonesia, 2007.

Suprayitno. 2014. Peran Permainan Tradisional Dalam Membantu Pertumbuhan Dan Perkembangan Gerak Anak Secara Menyeluruh. Jurnal Ilmu Keolahragaan Vol. 13 Nomor 2.

Widiastuti, Amellya Riza. 2015. Manajemen Federasi Olahraga Rekreasi Masyarakat Indonesia (Formi) Kota Semarang Tahun 2015. Semarang: UNNES Press 